\title{
Effect of Cooperative Learning on Secondary School Students' Mathematics Achievement
}

\author{
Effandi Zakaria $^{1}$, Titi Solfitri ${ }^{2}$, Yusoff Daud ${ }^{1}$, Zulkarnain Zainal Abidin ${ }^{2}$ \\ ${ }^{1}$ Faculty of Education, Universiti Kebangsaan Malaysia, Bangi, Malaysia \\ ${ }^{2}$ Faculty of Teacher Training and Education, Universiti Riau, Pekanbaru, Indonesia \\ Email: effandi@ukm.my
}

Received November 22 ${ }^{\text {nd }}, 2012$; revised December $27^{\text {th }}, 2012$; accepted January $6^{\text {th }}, 2013$

\begin{abstract}
The purpose of this study was to determine the effects of cooperative learning on students' mathematics achievement in secondary school students in Pekanbaru, Indonesia. In addition, this study also determined students' perception concerning cooperative learning. The samples of this study consisted of 61 Form Three students. In order to control the differences of dependent variables, a pre-test was given before treatment. After treatment, a post-test was administered to both groups. Two types of instruments were used to collect the data: the mathematics achievement test and open-ended questions on cooperative learning. The pre-test and the post-test data were analyzed using t-test. Content analysis was used for the open-ended questions on cooperative learning. The results showed that there was a significant difference of mean in students' mathematics achievement between the cooperative group and the traditional group. Content analysis data revealed that students in the cooperative group were able to increase their understanding and to develop their self-confidence.
\end{abstract}

Keywords: Mathematics Achievement; Jigsaw Cooperative Learning; Understanding; Self-Confidence

\section{Introduction}

Mathematics is still a subject that is considered difficult and boring to many students. According to Woodard (2004), weaker students feel anxiety toward mathematics, and this anxiety affects their performance in mathematics. Students who lack mastery in mathematics are less successful, despite being in secondary schools for a long period of time. Furthermore, low proficiency students in mathematics performed below average on the national tests in Indonesia. Based on observations of high school mathematics students, the information shows that students are not actively involved in developing knowledge; they receive information passively and are less motivated. This passivity has caused much concern among educators because knowledge of mathematics plays a significant role in enhancing the country's social economic development. The quality of education that teachers provide to students is dependent upon what teachers do in their classroom (Zakaria \& Iksan, 2007). The teaching method used in the class is one of the factors that make students become passive and have less interaction with each other in doing tasks. Lazarowitz, Hertz-Lazarowitz, and Baird (1994) have criticized the lecture method use by teachers because only hardworking students can benefit from it. Therefore, to enhance the understanding of mathematics, students must be more active in the classroom and must creatively acquire knowledge, especially in understanding and solving mathematical problems. Students should be given the opportunities to develop, to interact, and to share with friends through cooperative learning activity. Thus, the cognitive and affective development of students in mathematics can be improved. An alternative method for the delivery of material is cooperative learning. Zakaria and Iksan (2007) agree that in cooperative learning students work face to face to complete a given task collectively. Cooperative learning encourages students to be active participants in the construction of their own knowledge (Webb, Troper, \& Fall, 1995). Cooperative learning also encourages students to interact and to communicate with peers in harmony. In this way, cooperative learning promotes values such as honesty, cooperation, mutual respect, responsibility, tolerance, and willing to sacrifice a consensus. Execution of duties in cooperative learning can develop self-confidence in pupils. A study by Zakaria, Chin, and Daud (2010) found that cooperative learning improves students' achievement in mathematics. Further, cooperative learning is an effective approach that mathematics teachers need to incorporate into their teaching. Cooperative learning promotes deep learning of materials and helps students to achieve better grades (Shimazoe \& Aldrich, 2010). According to Johnson and Johnson (1989), in cooperative learning, students tend to enjoy mathematics, and this enjoyment motivates them to learn. Melihan and Sirri (2011) concluded that the cooperative learning method is more effective than the traditional teaching method in the academic success of students.

\section{Purpose and Objectives of the Study}

The purpose of this study is to determine the effects of jigsaw cooperative learning on achievement in mathematics. In addition, this study also looks at students' perceptions of jigsaw cooperative learning. The specific objectives of this study are as follows: 1) to determine whether there is a statistically significant difference in mathematics achievement between students taught using jigsaw cooperative methods and students taught using traditional methods and 2) to determine the perceptions of students when they are exposed to jigsaw cooperative learning. 


\section{Hypothesis of the Study}

The following null hypothesis was tested.

$\mathrm{H}_{01}$ - There is no significant difference in mathematics achievement between students who are exposed to jigsaw cooperative learning and those who are exposed to traditional methods.

\section{Methodology}

The design of this study is a quasi-experiment consisting of treatment group and a control group, since the classes existed as intact groups. Pre-tests were used to determine the equality of the two groups. This study consisted of 61 students, divided into two groups consisting of 30 students in the control group and 31 students in the treatment group. Treatment groups were exposed to jigsaw cooperative learning, while the control group was given the traditional teaching method. The teacher who implemented the jigsaw cooperative learning underwent training on the use of cooperative learning in order to ensure that it was implemented as planned. Upon completion of instruction, post-tests were conducted to determine the difference between the groups. Instruments used in this study were mathematics achievement tests and students' perceptions of jigsaw cooperative learning. Mathematics achievement is measured using performance test tools. The test consists of six open-ended questions and twelve multiple-choice items. The reliability coefficient (KR20) of the test was found to be 0.81 . The researchers in collaboration with mathematics teachers developed the questions. The questions cover integrals, area, and volume. The content of the tests was validated by a group of experts in mathematics education. This test was given to both groups before and after instruction was completed. A questionnaire was used to measure the students' perception towards cooperative learning. It contained five open-ended questions given to students who were exposed to cooperative learning methods. Content analysis was used to determine the response of students towards jigsaw cooperative learning. For this study, the response categories were developed as follows: 1) develop and label codes related to question; 2) record the results coded according to question; 3) incorporate the pattern into a single category; 4) determine the number of response categories combined; and 5) form tables and analysis. The conditions under which the instrument was administered were kept as similar as possible in order to control for interaction between selection and instrument (Gall, Gall, \& Borg, 2003).

\section{Findings}

\section{Analysis of Students' Mathematics Achievement}

Students in the experimental group had a mean score of 9.65 with a standard deviation of 5.58. Students in the control group had a mean score of 9.97 with a standard deviation of 6.10 . The t-test yielded a score of -.215 with 59 degrees of freedom, and the differences were not statistically significant. The results of the t-test are displayed in Table 1. Because there was no significant difference between the groups on the pre-test scores, it was possible to assess the difference between groups on the post-test by means of a t-test.

As shown in Table 2, having performed t-test, there was a statistically significant difference in the mean of mathematics achievement of students across the experimental groups and
Table 1.

Pre-test analysis of differences in mathematics achievement between the two groups.

\begin{tabular}{cccccc}
\hline & Mean & Std. deviation & $\mathrm{df}$ & $\mathrm{t}$-value & $p$-value \\
\hline Experimental & 9.65 & 5.58 & 59 & -.215 & .831 \\
Control & 9.97 & 6.10 & & & \\
\hline
\end{tabular}

Table 2.

Post-test analysis of differences in mathematics achievement between the two groups.

\begin{tabular}{cccccc}
\hline & Mean & Std. deviation & Df & t-value & $p$-value \\
\hline Experimental & 55.19 & 11.62 & 59 & 2.245 & .029 \\
Control & 47.47 & 15.10 & & & \\
\hline
\end{tabular}

control group at the alpha level of .05. Therefore, the null hypothesis was rejected. It can be concluded that the mathematics achievement of students through jigsaw cooperative learning was better than mathematics achievement of students undergoing traditional instruction.

\section{Analysis of Students' Perception of Cooperative Learning}

Table 3 presents the response of the respondents regarding cooperative learning. Students were asked to express their opinions about whether they liked their experience in jigsaw cooperative learning or not regarding and to state the reasons why. For those who preferred cooperative learning, the responses given by most students were being able to discuss and to exchange ideas with friends without fear $(26.1 \%)$, the idea that students can make friends and ask questions (23.2\%), enjoying learning in groups $(13.2 \%)$, more quickly understanding when a friend gave an explanation $(10.7 \%)$, and not being afraid if an error occurred (10.3\%), and being enthusiastic and motivated (7.5\%).

As shown in Table 4, the highest response was that jigsaw cooperative learning can enhance the students' understanding of the lessons learned, followed by the idea that cooperative learning raises their self-confidence and increases their motivation. The students also felt that cooperative learning improved their academic performance, created sense of togetherness among them, and gave them freedom to give opinions.

\section{Discussion}

\section{Effects of Cooperative Learning on Mathematics Achievement}

The results of this study indicate that cooperative learning methods result in higher mathematics achievement than the traditional teaching methods. A probable reason is that, when students explain and receive explanations from each other in group, they retain the new concepts much longer in their memory. They better understand what they have learned and therefore improve their performance. The cooperative approach has the element of accountability and interdependence embedded in a structure that is not found in the traditional classroom. This study supports the findings conducted by Zakaria et al. (2010) and Melihan and Sirri (2011). The positive impact produced by 
Table 3.

Perception of students' on jigsaw cooperative learning.

\begin{tabular}{ll}
\hline Response & Frequency (percent) \\
\hline $\begin{array}{l}\text { Can discuss and exchange views with } \\
\text { friends without fear }\end{array}$ & 26.1 \\
Can make friends and ask questions & 23.2 \\
Enjoy learning in a group & 13.2 \\
More quickly understand when a friend explain & 10.7 \\
Not afraid if an error occurred & 10.3 \\
Enthusiastic and motivated & 7.5 \\
Do not like to learn in group & 2.5 \\
Do not understand because they & 2.3 \\
cannot communicate & 2.2 \\
Discussion not focused & 2.0 \\
\hline Friends do not want to help & \\
\hline
\end{tabular}

Table 4.

Effect of cooperative learning on students.

\begin{tabular}{ll}
\hline Response & Frequency (percent) \\
\hline Enhance understanding & 59.3 \\
Raises confidence & 15.6 \\
Increase motivation & 8.3 \\
Improve academic performance & 7.0 \\
Sense of togetherness & 6.4 \\
Free to give opinion & 3.4 \\
\hline
\end{tabular}

cooperative learning shows the importance of student interaction as proposed by Vygotsky and Piaget.

\section{Student Perceptions towards Jigsaw Cooperative Learning}

The results showed that students prefer jigsaw cooperative learning. The percentage of students who prefer cooperative learning is higher than the percentage of students who do not like cooperative learning. The students in the study perceived that cooperative learning was beneficial to them. In short, they were willing to help and to cooperate with each other and to promote each other's learning. These attitudes help to build group identity and create an environment conducive to learning (Slavin, 1996). However, it should be noted that some students preferred not to work in group, meaning that cooperative learning is not for everyone (Arra, D'Antonio, \& D'Antonio, 2011). Teachers should be aware of students' preferences in learning.

\section{Conclusion}

The results reveal that cooperative learning can increase mathematics achievement. Cooperative learning also enhances understanding and self-confidence. These results would imply that incorporating cooperative learning in the mathematics classroom would enhance the learning of mathematics in secondary schools. Implementation of jigsaw cooperative learning should be reviewed in terms of knowledge and skills of each teacher. In this case, training and continuous professional development is needed for teachers, and collaboration among teachers should be encouraged through holding regular meetings, both formal and informal. Teachers can learn from each other and can examine the strengths and weaknesses of the instruction that has been implemented, and their experience can be shared with each other to produce better work.

\section{REFERENCES}

Arra, C. T., D’Antonio, M. D., \& D’Antonio Jr., M. (2011). Students' preferences for cooperative learning instructional approaches: Considerations for college teachers. Journal of Research in Education, 21, 114-126.

Gall, M. D., Gall, J. P., \& Borg, W. R. (2003). Educational research: An introduction (7th ed.). Boston: Allyn \& Bacon.

Johnson, D. W., \& Johnson, R. T. (1989). Cooperation and competition: Theory and research. Edina, MN: Interaction.

Lazarowitz, R., Hertz-Lazarowitz, R., \& Baird, J. (1994). Learning science in a cooperative setting: Academic achievement and affective outcomes. Journal of Research in Science Teaching, 31, 1121-1131. doi:10.1002/tea.3660311006

Melihan, U., \& Sirri, A. (2011). The effect of cooperative learning method on the students' success and recall levels of the 8th grade students learning in permutation and probability subject. Journal of Kirsehir Education Faculty, 12, 1-16.

Shimazoe, J., \& Aldrich, H. (2010). Group can be gratifying: Understanding and overcoming resistance to cooperative learning. College Teaching, 58, 52-57. doi:10.1080/87567550903418594

Slavin, R. E. (1995). Cooperative learning: Theory, research, and practice. Boston: Allyn \& Bacon.

Slavin, R. E. (1996). Research on cooperative learning and achievement: What we know, what we need to know. Contemporary Educational Psychology, 21, 43-69. doi:10.1006/ceps.1996.0004

Webb, N., Troper, J., \& Fall, R. (1995). Constructive activity and learning in collaborative small groups. Journal of Educational Psychology, 87, 406-423. doi:10.1037/0022-0663.87.3.406

Woodard, T. (2004). The effects of math anxiety on post-secondary developmental students as related to achievement, gender, and age. Inquiry, 9. URL (last checked 24 October 2012). http://www.vccaedu.org/inquiry/

Zakaria, E., Chin, L. C., \& Daud, M. Y. (2010). The effects of cooperative learning on students' mathematics achievement and attitude towards mathematics. Journal of Social Science, 6, 272-275.

Zakaria, E., \& Iksan, Z. (2007). Promoting cooperative learning in science and mathematics education: A Malaysia perspective. Eurasia Journal of Mathematics, Science \& Technology Education, 3, 35-39. 